УдК 616.932

\title{
Е.В.Монахова ${ }^{1}$, Г.М.Федоренко ${ }^{2}$, А.Б.Мазрухо ${ }^{1}$, Р.В.Писанов ${ }^{1}$, В.Д.Кругликов ${ }^{1}$, О.В.Маркина ${ }^{1}$, Л.П.Алексеева ${ }^{1}$
}

\section{ИЗУЧЕНИЕ БИОЛОГИЧЕСКОГО ДЕЙСТВИЯ ЦИТОТОНИЧЕСКОГО ФАКТОРА СЕF ХОЛЕРНЫХ ВИБРИОНОВ НА МОДЕЛЯХ IN VITRO И IN VIVO}

\author{
${ }^{I}$ ФКУЗ «Ростовский научно-исследовательский противочумный институт», \\ ${ }^{2}$ Южный Научный Центр РАН, Ростов-на-Дону
}

\begin{abstract}
Изучены морфологические, физиологические и ультраструктурные изменения в культуре клеток L-929 и кишечнике мышей-сосунков под действием препарата $\mathrm{Cef}$ (CHO cell elongating factor) холерных вибрионов. В культуре происходило удлинение клеток, вакуолизация их цитоплазмы, увеличение числа лизосом, ретракция и деформация ядер. In vivo Cef вызывал статистически достоверное накопление жидкости. При электронномикроскопическом исследовании эпителиоцитов тонкого кишечника наблюдалось образование вакуолей и миелиноподобных структур в цитоплазме и ядрах, набухание митохондрий, просветление их матрикса и деструкция крист. В криптах отмечалось скопление слизи. Вовлечение в процесс тучных клеток приводило к усугубляющему дегидратацию повышению проницаемости капилляров. Эти изменения свидетельствуют об участии Cef в проявлении холерными вибрионами патогенных свойств.
\end{abstract}

Ключевые слова: CHO cell elongating factor, холерный вибрион, культура клеток, тонкая кишка, ультраструктура.

\section{E.V.Monakhova ${ }^{1}$, G.M.Fedorenko' ${ }^{2}$, A.B.Mazrukho ${ }^{1}$, R.V.Pisanov ${ }^{1}$, V.D.Kruglikov ${ }^{1}$, O.V.Markina ${ }^{1}$, L.P.Alekseeva ${ }^{1}$}

\section{Study of Biological Effect of CHO-Cell Elongating Factor of Vibrio cholerae on Models in vitro and in vivo}

\author{
${ }^{1}$ Rostov-on-Don Research Anti-Plague Institute, ${ }^{2}$ Southern Scientific Centre of Russian Academy of Sciences, Rostov-on-Don
}

\begin{abstract}
Studied were morphological, physiological and ultrastructural changes in the cell culture L-929 and in the intestine of suckling mice in the presence of Cef (CHO cell elongating factor) of Vibrio cholerae. Registered were cellular elongation, cytoplasm vacuolization, an increase in the number of lysosomes, retraction and nuclei deformation in the L-929 cell culture. Statistical significance test confirmed that in vivo Cef caused the accumulation of fluid in suckling mice. Electron microscopy of the epithelial cells of small intestine revealed vacuolization and myelin-like structures formation in cytoplasm and nuclei, swelling of mitochondria, clarification of their matrix and destruction of cristae. Cristae were filled with mucus. The involvement of mast cells caused the increasing of capillary permeability which enhanced dehydration. These changes confirmed Cef participation in manifestation of Vibrio cholerae pathogenic properties.
\end{abstract}

Key words: CHO cell elongating factor, Vibrio cholerae, cell culture, small intestine, ultrastructure.

Cef (CHO cell elongating factor), идентифицированный В.A.McCardell et al. [4, 5], относится к числу малоизученных предполагаемых факторов вирулентности холерных вибрионов. Ранее мы сообщали о клонировании гена cef Vibrio cholerae в плазмидном векторе pBAD18 и его экспрессии в E. coli под контролем $\mathrm{P}_{\text {BAD }}$-промотора $[2,3]$. Осветленные ультразвуковые дезинтеграты рекомбинантных штаммов кишечной палочки обладали всеми свойствами, описанными в литературе для Cef, выделенного из культуральной жидкости $V$. cholerae, а именно эстеразной активностью, способностью вызывать удлинение клеток CHO и L-929, а также накопление жидкости в кишечнике мышей-сосунков $[4,5,6]$. Эти данные свидетельствовали о возможности использования рекомбинантных штаммов E. coli, содержащих клонированный ген cef, в качестве продуцентов искомого белка с целью выделения его препаратов, необходимых для выяснения значимости Cef в патогенезе холеры, особенно вызываемой нехолерогенными штаммами. Механизм действия Cef на эукариотические клетки не изучен. Известно лишь то, что он отличен от такового холерного токсина (CT), поскольку в обработанных Cef удлиненных клетках $\mathrm{CHO}$ не было выявлено повышения уровней цАМФ и простагландина $\mathrm{E}_{2}[4,5]$. Получению ответов на поставленные вопросы могут способствовать дальнейшие исследования биологического действия Cef на лабораторных моделях, в том числе электронно-микроскопические, которые до настоящего времени не проводились.

Целью настоящей работы явилось изучение морфологических, физиологических и ультраструктурных изменений в культуре клеток L-929 и тонкой кишке мышей-сосунков при действии препарата Cef холерных вибрионов.

\section{Материалы и методы}

В качестве продуцента Cef V. cholerae классического биовара был использован сконструированный нами рекомбинантный штамм E. coli Jm103pCef69B $[2,3]$. Наращивание биомассы с индукцией арабинозой проводили как описано ранее [2]. Препарат выделяли из 2 г сырой бактериальной массы, раз- 
рушенной ультразвуком в 50 мл лизис-буфера (8 M мочевина, 10 мМ ЭДТА, pН 8,0). Полученный лизат доводили до 200 мл дистилированной водой, осветляли центрифугированием при 15000 об./мин в течение 20 мин, насыщали сульфатом аммония (CA), $\mathrm{pH} 8,0$, до $50 \%$ и инкубировали в течение 12 ч при $4{ }^{\circ} \mathrm{C}$. Осадок отделяли центрифугированием при 15000 об./мин в течение 20 мин и растворяли в буфере для гель-фильтрации (200 мМ СА, 10 мМ Трис, 1 мМ ЭДТА, 1 \% изопропанол, $\mathrm{pH} 8,0)$. Раствор наносили на колонку для гель-фильтрации HW-55F (Farmacia). Ферментативную активность фракций определяли в лунках агара, содержащего твин 20 или трибутирин как описано ранее [2]. Активные фракции объединяли, уравновешивали буфером (50 мМ CA, 10 мМ Трис, 1 мМ ЭДТА, 1 \% изопропанол, $\mathrm{pH} 8,0$ ) и наносили на колонку для ХОФ (хроматография в обращенной фазе) с Butil-Toyopearl $650 \mathrm{M}$ (Toysoda). Элюцию вели снижающимся градиентом СА от 50 мМ до 0. Активные фракции объединяли, концентрировали и прогревали при $56{ }^{\circ} \mathrm{C}$ в течение 60 мин, после чего осаждали центрифугированием денатурированные балластные белки и собирали прозрачный супернатант. Препарат проверяли на эстеразную активность, степень его очистки контролировали электрофоретически.

Для оценки биологической активности Cef in vitro использовали культуру клеток подкожной соединительной ткани мыши L-929 (Институт цитологии РАН, Санкт-Петербург), поскольку наши предшествующие исследования показали, что в этой культуре удлинение клеток под действием Cef выражено более четко по сравнению с СНО [2]. Количественное определение активности проводили в 96-луночных пластиковых планшетах как описано ранее [2], для электронно-микроскопического исследования клетки выращивали в пластиковых флаконах (матрасиках) до образования плотного монослоя в среде RPMI-1640 (Sigma) с $10 \%$ сыворотки плода коровы в течение 1-2 сут. Непосредственно перед опытом полную ростовую среду заменяли на свежую, содержащую 1 \% сыворотки и 100 мкг/мл гентамицина. Испытуемый препарат добавляли к культурам до конечной концентрации 10 мкг/мл и инкубировали в $\mathrm{CO}_{2}$-инкубаторе (Sanjo) при $37^{\circ} \mathrm{C}$ в течение суток. Морфологическое изучение культур проводили с помощью инвертированного микроскопа (Reichert). Для фотографирования клетки фиксировали формальдегидом и окрашивали по Романовскому-Гимза.

Для изучения биологической активности in vivo мышам-сосункам 4-5-дневного возраста вводили ректально по 10 мкг препарата в 100 мкл $10 \mathrm{Mм}$ трис-HCl (pH 7,5), контрольным - по 100 мкл того же буфера без Cef. Опытная и контрольная группы включали по 10 животных каждая. Через 5 ч мышей умерщвляли хлороформом и определяли $\mathrm{FA} \pm \mathrm{SD}$ (отношение веса ЖКТ к весу тела \pm стандартное отклонение). Статистическую обработку результатов проводили с помощью программы Primer of Biostatistics v.4.03.
Для электронно-микроскопического исследования клетки культуры (после удаления культуральной жидкости) и кусочки тонкой кишки мышей-сосунков (по 4 животных, отобранных из опытной и контрольной групп) фиксировали в 2,5 \% в растворе глутарового альдегида на 0,1 М фосфатном буфере $(\mathrm{pH} 7,4)$ в течение 20 мин, дофиксировали в $1 \%$ растворе четырехокиси осмия в том же буфере в течение 1,5 ч при $4{ }^{\circ} \mathrm{C}$. После обезвоживания в спиртах восходящей концентрации материал заключали в эпон 812 . Срезы, полученные на ультрамикротоме LKB-8800, контрастировали уранилацетатом и цитратом свинца и просматривали в электронном микроскопе Tecnai 12 (Philips).

\section{Результаты и обсуждение}

Спустя сутки после внесения препарата Cef в культуру L-929, выращенную монослоем, в световом микроскопе наблюдалось удлинение клеток (рис. 1, б), отсутствующее в контроле (рис. 1, а), выраженное, однако, немного слабее, чем при тестировании на отдельных клетках [2]. При электронномикроскопическом исследовании удлиненных клеток наиболее заметными изменениями были вакуолизация цитоплазмы, а также резкое увеличение числа лизосом (рис. 1, г, е). Вакуоли содержали электронно-плотные частицы, представляющие, вероятно, продукты распада, которые выбрасывались
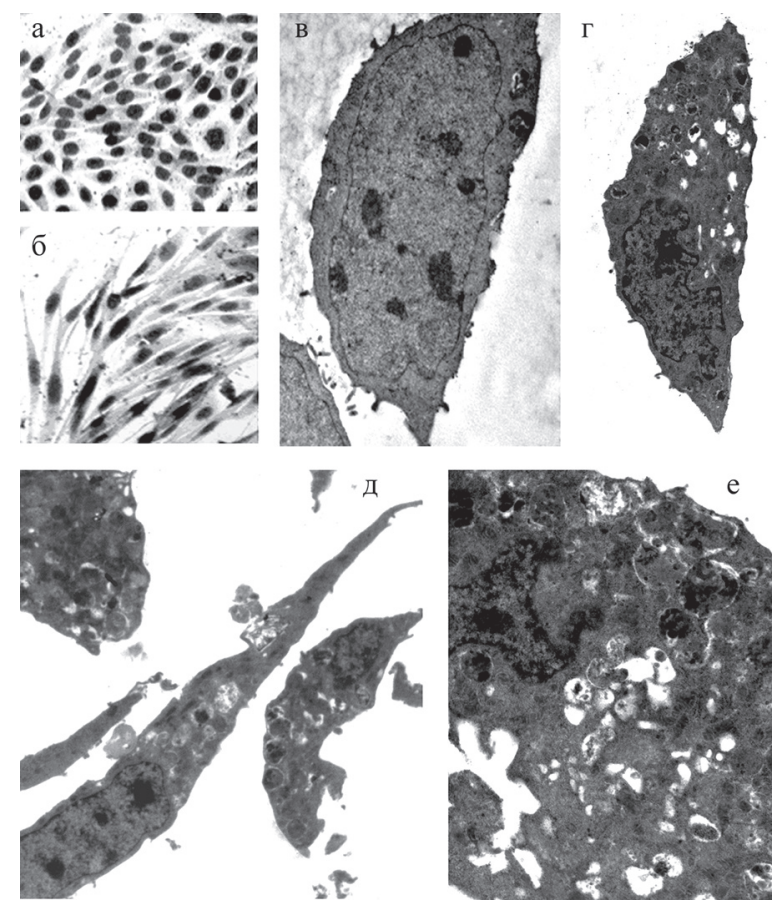

Рис. 1. Морфологические и ультраструктурные изменения в культуре клеток L-929, вызванные действием препарата Cef:

$a$ - контрольные клетки; $\sigma$ - обработанные препаратом клетки под световым микроскопом, окраска по Романовскому-Гимза, $\times 150$;

в - ультраструктура контрольной клетки, $\times 8200 ; 2$ - вакуолизация цитоплазмы, увеличение числа лизосом и смещение ядра на периферию клетки, обработанной Cef, ×6000; $\partial$ - образование вакуолей и освобождение их содержимого через разрывы клеточной стенки, ×4200; $e$ - деформация ядра, вакуолизация цитоплазмы и увеличение числа лизосом, $\times 11500$ 

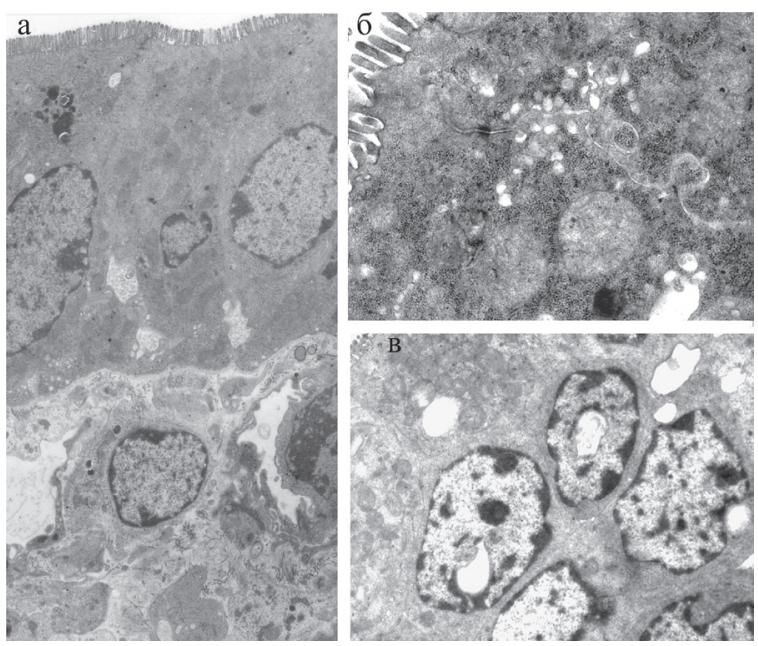

Рис. 2. Ультраструктурные изменения в эпителиоцитах тонкой кишки мышей-сосунков под действием Cef $V$. cholerae:

$a$ - контроль, $\times 3000 ; \sigma-$ набухание митохондрий, разрушение их крист, образование в цитоплазме множественных мелких и отдельных

крупных вакуолей (некоторые содержат миелиноподобные структуры), $\times 20500 ;$; - вакуоли в цитоплазме, внутри набухших митохондрий и ядер, $\times 6000$

во внеклеточное пространство через разрывы цитоплазматической мембраны (рис. 1, д). Во многих клетках имели место ретракция и деформация ядер либо их смещение на периферию клетки (рис. 1, г, е). Каких-либо заметных изменений со стороны митохондрий выявлено не было (данные не показаны).

Препарат Cef вызывал в кишечнике мышейсосунков статистически достоверное накопление жидкости. В группах опытных и контрольных животных средние показатели $\mathrm{FA} \pm \mathrm{SD}$ составляли соответственно $0,078 \pm 0,005$ и $0,059 \pm 0,005(\mathrm{P}=0,000)$.

При электронно-микроскопическом исследовании тонкого кишечника мышей-сосунков спустя 5 ч после введения препарата Cef наблюдались изменения, отсутствующие в кишечнике контрольных животных (рис. 2, а) и отличные от характерных для действия СТ [1], что косвенно подтверждает данные McCardell B.A. et al. $[4,5]$ о том, что механизм действия Cef отличен от такового СТ.

В эпителиоцитах присутствовали в большом количестве мелкие вакуоли и отдельные более крупные. По-видимому, многие из них представляли собой фаголизосомы, содержащие продукты распада цитоплазмы и клеточных органелл, а также миелиноподобные структуры. Последние также находились в цитоплазме, митохондриях, лизосомах. Происходило набухание митохондрий, просветление их матрикса и деструкция крист. Наблюдалось повреждение ядер, проявляющееся в образовании крупных полостей в кариоплазме (рис. 2, б, в). Несмотря на выраженную вакуолизацию, характерная для действия СТ баллонная дистрофия не развивалась.

Микроворсинки и апикальные мембраны клеток щеточной каймы оставались практически неповрежденными, лишь на отдельных участках имела место частичная деградация микроворсинок и микроклазматоз (рис. 3, а). В криптах отмечалось скопление
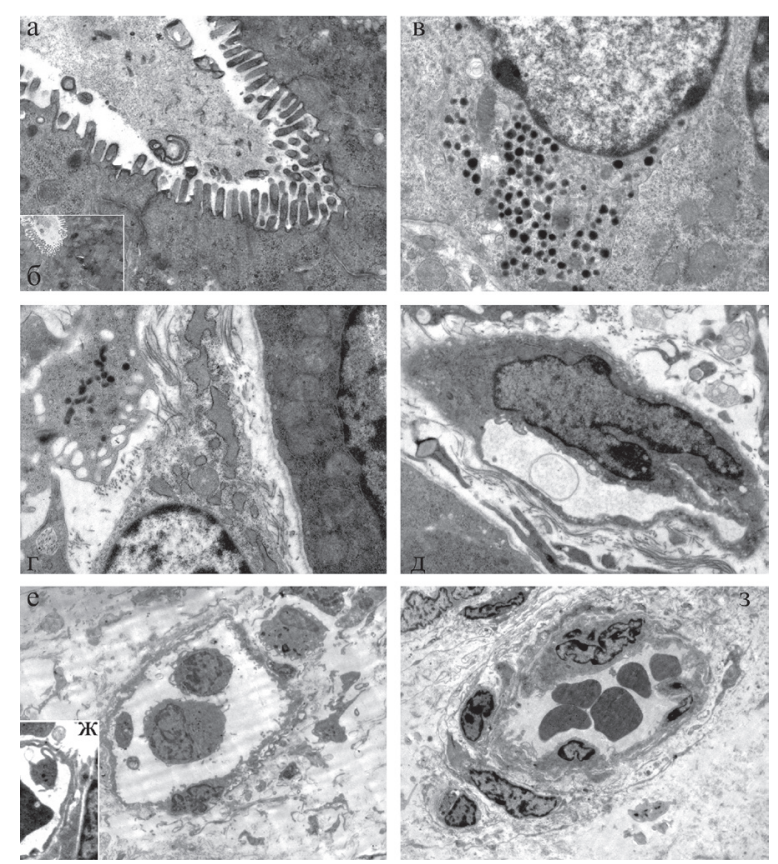

Рис. 3. Ультрастуктурные изменения в тонкой кишке мышей-сосунков под действием Cef:

$a$ - частичная деградация микроворсинок и микроклазматоз в щеточной кайме, $\times 16500 ; \sigma$ - бокаловидная клетка, освобождающая слизь в просвет крипты, $\times 6000 ;$ в - вакуоли и миелиноподобные структуры в Ес-клетке, $\times 9900 ; 2$ - частичная дегрануляция тучной клетки, $\times 11500 ; \partial-$ пиноцитозные везикулы в стенке капилляра стромы, $\times 8200 ; e-$ усиление трансэндотелиального микропиноцитоза и появление микродефектов в эндотелиальной выстилке, $\times 2550$; $ж$ - адгезия тромбоцита в участке деструкции капилляра, $\times 2250$; 3 - капилляр контрольного животного, $\times 2250$

слизи (рис. 3, б).

В энтерохромаффинных (ЕC) клетках наряду с электронноплотными гранулами присутствовали гранулы с признаками либерации их содержимого (серотонина, мотилина), однако дегрануляции не происходило. В то же время в цитоплазме наблюдалось образование вакуолей и миелиноподобных структур, что свидетельствовало о серьезных структурнофункциональных нарушениях (рис. 3, в).

Тучные клетки выглядели частично дегранулированными (рис. 3, г), что указывает на умеренное освобождение в строму гормональных веществ, повышающих сосудистую проницаемость (гистамина, гепарина, серотонина). Соответственно, в близлежащих капиллярах наблюдалось усиление микропиноцитоза и появление микродефектов в эндотелиальной выстилке (рис. 3, д, е). Повреждения эндотелия вызывали защитную реакцию - адгезию тромбоцитов в участках деструкции (рис. 3, ж).

Выраженная вакуолизация цитоплазмы свидетельствует о нарушениях водно-электролитного баланса как в культивируемых клетках, так и в эпителии кишечника, что приводит к наблюдаемым внешним изменениям in vitro и in vivo. По всей вероятности, в том и другом случае они являются следствием обезвоживания клеток. Последнее, в свою очередь, вызывает повреждения внутриклеточных органелл, продукты распада которых перевариваются активизированным лизосомальным аппаратом. На уровне 
макроорганизма это обезвоживание усугубляется вовлечением в процесс тучных клеток и, как следствие, дополнительной потерей жидкости через стенки кровеносных сосудов. Предстоит еще выяснить, каким образом, непосредственно или опосредованно, Cef «запускает» процесс начальной вакуолизации, однако его способность вызывать тяжелые повреждения структурных элементов тонкого кишечника определенно указывает на причастность этого фактора к проявлению холерными вибрионами патогенных свойств, что, в первую очередь, относится к нехолерогенным штаммам $V$. cholerae.

\section{СПИСОК ЛИТЕРАТУРЫ}

1. Власов В.П., Харланова Н.Г., Монахова Е.В, Винокур Н.И., Бардахчьян Э.А. Ультраструктурные изменения в тонкой кишке, вызванные холерогенным и нехолерогенным штаммами вибрионов. Доклады АН. 1997; 352:278-80.

2. Монахова Е.В., Ломов Ю.М., Писанов Р.В., Алексеева Л.П., Маркина О.В., Миронова А.В. и др. Клонирование гена цитотонического фактора Cef (CHO-cell elongating factor) Vibrio cholerae в Escherichia coli и его экспрессия под контролем $\mathrm{P}_{\mathrm{BAD}}$ промотора. Биотехнология. 2006; 5:12-8.

3. Монахова Е.В., Ломов Ю.М., Писанов Р.В., Алексеева Л.П., Маркина О.В., Веркина Л.М., Миронова А.В. Рекомбинантная плазмида, экспрессирующая клонированный ген cef (CHO cell elongating factor) Vibrio cholerae (варианты) и штамм Escherichia coli - продуцент cef (CHO cell elongating factor) Vibrio cholerae (варианты). Патент РФ 2313577, опубл. 27.12.07. Бюл. 36.

4. Mc Cardell B.A., Kothary M.H., Hall R.N., Sathyamoorthy V. Identification of a CHO-elongating factor produced by Vibrio cholerae O1. Microb. Pathogen. 2000; 29(1):1-8.

5. McCardell B.A. Sathyamoorthy V., Michalski J., Lavu S. Kothary M., Livezey J. et al. Cloning, expression and characterization of the $\mathrm{CHO}$ cell elongating factor (Cef) from Vibrio cholerae $\mathrm{O} 1$. Microb. Pathog. 2002; 32:165-72.

6. Sathyamoorthy V., Hall R.H., McCardell B.A., Kothary M., Ahn S.J., Ratnayake S. Purification and characterization of a cytotonic protein expressed in vitro by the live cholera vaccine candidate CVD 103-HgR. Infect. Immun. 2000; 68:6062-5.

References (Presented are the Russian sources in the order of citation in the original article)

1. VlasovV.P., Kharlanova N.G., Monakhova E.V., Vinokur N.I., Bardakhch'yan E.A. [Ultrasructural changes in the large intestine, caused by choleragenic and non-choleragenic vibrio strains]. Doklady AN. 1997; 352:278-80.

2. Monakhova E.V., Lomov Yu. M., Pisanov R.V., Alekseeva L.P. Markina O.V. Mironova A. V. et al. [Cloning of the gene of Vibrio cholerae $\mathrm{CHO}-$ cell elongating factor and its expression under control of $\mathrm{P}_{\mathrm{BAD}}$ promoter]. Biotekhnologia. 2006; 5:12-8.

3. Monakhova E.V., Lomov Yu. M., Pisanov. R.V., Alekseeva L.P., Markina O.V., Verkina L.M., Mironova A.V." [ Recombinant plasmid, expressing the cloned cef ( $\mathrm{CHO}$ cell elongating factor) of Vibrio cholerae (variants) and Escherichia coli strain - producer of cef ( $\mathrm{CHO}$ cell elongating factor) of Vibrio cholerae (variants)]. RF Patent № 2313577.

Authors:

Monakhova E.V., Mazrukho A.B., Pisanov R.V., Kruglikov V.D., Markina O.V., Alekseeva L.P. Rostov-on-Don Research Anti-Plague Institute. M.Gor'kogo St., 117/40, Rostov-on-Don, 344002, Russia. E-mail: plague@aaanet.ru

Fedorenko G.M. Southern Scientific Centre of Russian Academy of Sciences. Rostov-on-Don.

Об авторах:

Монахова Е.В., Мазрухо А.Б., Писанов Р.В., Кругликов В.Д., Маркина O.В., Алексеева Л.П. Ростовский-на-Дону научно-исследовательский противочумный институт. 344002, Ростов-на-Дону, ул. М.Горького, 117/40. E-mail: plague@aaanet.ru

Федоренко Г.М. Южный Научный Центр РАН. Ростов-на-Дону.

Поступила 17.08.11 